\title{
Psychological Capital (PsyCap) Resources and its Relations with Creative Self-efficacy in Entrepreneurship Students
}

\begin{abstract}
This study aims to analyse Psychological Capital (PsyCap) and creative self-efficacy of students participating in the entrepreneurship program. The theory of the paper analyses the development and significance of concepts. Quantitative research focuses on finding out the levels of PsyCap and creative self-efficacy, comparing PsyCap data to a representative sample, comparing all results with the current job status and their entrepreneurial intentions.
\end{abstract}

Keywords: Psychological Capital (PsyCap), creative self-efficacy, entrepreneurship.

Šio tyrimo metu siekiama išanalizuoti studentų, dalyvavusių verslumo programoje, psichologinị kapitalą (PsyCap) ir kūrybinị saviveiksmingumą. Straipsnio teorineje dalyje analizuojama sąvokų raida ir svarba. Kiekybinis tyrimas skirtas analizuoti PsyCap ir kūrybinio saviveiksmingumo lygius, palyginti PsyCap duomenis su reprezentatyvia imtimi, visus rezultatus ịvertinti pagal dabartinę darbo padètị ir verslumo ketinimus.

Raktiniai žodžiai: psichologinis kapitalas (PsyCap), kūrybinis saviveiksmingumas, antreprenerystè.

\section{Introduction}

In the climate of the pandemic after the governments have imposed quarantines, even within the largest economies, the fear emerges about approaching financial recession and grim prospects (Nicola et al., 2020). It may become more fundamental than during prior periods of steadier societal development and financial lifecycle to accrue so-termed psychological resources (Hobfoll, 2002), particularly, psychological capital (PsyCap) that has been becoming a focus for the last couple of decades in the organisational management to optimise human systems to thrive in the workplace (Luthans, 2002) as insufficient knowledge and understanding of individual potential may result in poor company's capabilities to mobilise its human recourses (Hsu et al., 2014). Young entrepreneurs who are ready to enter the professional world may face more obstacles and restraints, and high psychological capital may be advantageous as it has proved to have a significant and positive impact on entrepreneurs' job satisfaction, performance, attitude, and organizational citizenship behaviour (Wang et al., 2018).

\footnotetext{
Evelina SAVICKAITÉ-KAZLAUSKE் - PhD student at the Faculty of Economics and Management, Vytautas Magnus University, Lithuania; partnership docent at Minded VDU, Vytautas Magnus university, Lithuania. Address: S. Daukanto str. 28, room 206, LT-44244 Kaunas, Lithuania. Phone: 37037207166.

E-mail: evelina.savickaite-kazlauske@vdu.lt
} 
Creative self-efficacy factor could be indispensable to show greater innovation (Hsu et al., 2011) generating new ventures and sustaining them in the unforeseeable future as it has been suggested that creativity may play an important role in enhancing organisational effectiveness, to survive and thrive in changing environments (Liu et al., 2016). Creativity may relate to psychological capital (PsyCap) (Luthans et al., 2004), consequently it may be important to explore whether creative self-efficacy could have strong correlations, too.

Thus, based on the literature review, the research object is to analyse how students who completed entrepreneurship programme estimate their psychological capital (PsyCap) and creative self-efficacy resources, as well as to find out whether the PsyCap and creative self-efficacy have significant correlations.

The aims of the study are were: 1) to measure students estimated psychological capital (PsyCap) and compare it to the young people's representational sample data; 2) to measure how they estimate their creative self-efficacy resources and whether the findings have a correlation with psychological capital (PsyCap).

The research methods. The sample consisted of 43 Entrepreneurship Academy students (34.9\% (15) male, $65.1 \%$ (28) female). The quantitative methods have been used to collect the data. Psychological Capital (PsyCap) has been evaluated using the PCQ-24 test (Luthans et al., 2007), creative self-efficacy was measured with creative self-efficacy scale (Tierney, Farmer, 2002).

The objectives of the article are to review the corresponding literature to present the concepts and their interconnections, present and interpret results, as well offer the discussion for the presence or absence of the anticipated correlations or differences.

\section{Psychological Capital}

M. E. P. Seligman's (1997) initiated the advent of scientific positive psychology research led its way not only to personal growth (as cited in Seligman, Csikszentmihalyi, 2000) but permeated into education and business realm (Shatté et al., 2000). Positive Organisation Scholarship marks the entrance into the latter sector, and it could be described as a "movement in organizational science that focuses on the dynamics leading to exceptional individual and organizational performance such as developing human strength, producing resilience and restoration, and fostering vitality" (Cameron, Caza, 2004, p. 731). Its individual-focused counterpart Positive Organizational Behaviour, or POB, could be defined as "the study and application of positively oriented human resource strengths and psychological capacities that can be measured, developed, and effectively managed for performance improvement" (Luthans, Church, 2002, p. 59). POB, upon arrival to the organisational entities, offers a variety of positive scientific perceptions, including strengths, wider perspective into organisational dynamics, processes, and outcomes (Luthans, Youssef-Morgan, 2017).

To coin the measure of the individual positive resources, F. Luthans, J. B. Youssef, and B. J. Avolio (2004) proposed a term of psychological capital, or PsyCap - an equivalent alongside social, 
intellectual or economic capitals. The latter consumed much focus in the past, and other capitals plead to gain greater independence to offer more advantages (Luthans et al., 2004). PsyCap is a multidimensional construct, defined as an individual positive psychological developmental stance with categories of selfefficacy: confidence in accomplishing challenging goals with efforts; hope: perseverance toward goals and, if necessary, reconstructing paths to ensue; resilience: in times of obstacles and adversity, withstanding and bouncing back and beyond; and optimism: adapting positive attributions to current and future prospects (Luthans, 2002; Luthans et al., 2004; Luthans, Youssef, et al., 2007).

Self-efficacy holds that humans are active agents in their lives rather than passive responders to the environmental events, determining whether an individual will initiate coping strategies, how much energy he will devote and how long she can sustain formidable experiences (Bandura, 1977). In metanalysis of self-efficacy's relation to performance at work, A. Stajkovic and F. Luthans (1998) have gathered extensive empirical evidence, where a self-efficacious employee in his workplace has confidence in his capacity to accumulate the inner resources and choose behavioural strategies to complete tasks (Stajkovic, Luthans, 1998).

Hope, based on C. R. Snyder's (1991) theory-building and research, is defined as "cognitive set that is based on a reciprocally derived sense of successful (a) agency (goal-directed determination) and (b) pathways (planning of ways to meet goals)" (Snyder et al., 1991, p. 571). Hope has been related to performance in the workplace via evidence of many empirical works and theoretical considerations (Jensen, Luthans, 2006; Avey et al., 2009, Luthans et al., 2010; Harms, Luthans, 2012).

Resilience. Resilience could be defined as "the developable capacity to rebound or bounce back from adversity, conflict, and failure or even positive events, progress, and increased responsibility" (Luthans, Youssef et al., 2007, p. 18). It has been researched in the organisational context (Luthans, Vogelgesang et al., 2006), as occurring failures may stop employees from progressing and lead to helplessness (Hsu et al., 2014).

Optimism, according to M.E. P. Seligman (1998) is an explanatory style, where optimists explicate the events as internal, stable and global, whereas negative events as external, unstable and specific. Oppositely, pessimists would interpret achievement as external, temporary and situation-specific, whilst negative environmental factors would be treated as permanent, personal and pervasive (as cited in Carvier, Scheier, 2002; Peterson, Steen, 2002). It can be developed, and its positive effects have been empirically investigated within the organisational context (Youssef, Luthans, 2007, Luthans et al., 2010).

\section{Positive PsyCap outcomes and opportunities for development}

The employee's positive psychological state may raise the confidence to take positive risks, recreate pathways to achieve goals and sustain in challenging circumstances (Tang, 2020a). However, 
businesses and organisations require observable and tangible outcomes to see how PsyCap could mark a significant impact. A large body of evidence drawn from a wide range of cultural and organisational backgrounds could already provide some promising outcomes (Luthans, YoussefMorgan, 2017), where PsyCap can be developed and sustained to generate greater competitive advantage, predict individuals' resources to pursue the goals, solve problems, indicate higher creative performance, and demonstrate financial growth in the organisation (Newman et al., 2014). Also, PsyCap comprising state-like rather than trait-like components, is malleable (Luthans, Avey et al., 2006; Luthans et al., 2008; Luthans et al., 2010) and it can be developed via mastery experience, mediated experiences or modelling, social persuasion, awareness and management of physiological and psychological resources, etc. (Luthans et al., 2004; Youssef, Luthans, 2007).

\section{Entrepreneurship and PsyCap}

In entrepreneurship, PsyCap is considered a key aspect of creating a business (Hmieleski et al., 2015), where optimism and self-efficacy could influence new venture success (Hmieleski, Baron, 2009). A considerable body of psychological capital research has been conducted so far (Newman et al., 2014), however, only some have investigated PsyCap in entrepreneurs (Pease, Cunningham, 2016), either current or future. Future entrepreneurs to create their own ventures need to develop intention, which Bird (1988) describes as an individual focus on a goal and a path to achieve it (as cited in Hizam-Hanafiah et al., 2017), where PsyCap could serve considerably. Studies show that there are positive relationships of psychological capital, its subscales of hope and self-efficacy with growth intentions of entrepreneurs (Hizam-Hanafiah et al., 2017), and high self-efficacy individuals often choose challenging tasks to improve their performance and cope against all obstacles to meet their goals (Cavus, Kapusuz, 2015, Tang, 2020b); which can lead to higher competitive advantage (Tang, 2020b). Finally, entrepreneurial learning has a reciprocal influence on entrepreneurial proficiency via the mediation of PsyCap (Hasan et al., 2019).

\section{Creative self-efficacy and its relation to PsyCap and entrepreneurship}

Entrepreneurship may be described as a value creation process for business and social communities, merging and multiplying public and private resources (Fillis, Rentschler, 2010), where creative means are at the forefront of establishing or sustaining new ventures, and it can be an important factor in surviving the competitive environment (Tang, 2020a).

A. Bandura (1997) determined that self-efficacy is an essential condition for creative productivity because personal views on their capacity have an impact on their motivation and proactive behaviour (Bandura, 1977). Creative self-efficacy is a construct developed by P. Tierney and S. M. Farmer (2002) which could be defined as "the belief one has about the ability to produce creative outcomes"(Tierney, Farmer, 2002, p. 1138). Individuals who indicate higher 
creative self-efficacy may seek and integrate diverse information, which in turn may generate creative outcomes (Tierney, Farmer, 2002; Chen, Zhang, 2019); engage in innovative endeavours at work due to self-reliance in their skills to generate and implement ideas (Jiang, Gu, 2017); and demonstrate more creativity in a workplace setting (Tierney, Farmer, 2011). The research shows an indirect relationship between creative self-efficacy with creativity (Li et al., 2020), and it is thought to mediate the relationship between creative potential and creative performance (Karwowski, 2016), or between goal orientation and creativity (Gong et al. 2009). Finally, creative selfefficacy is a malleable construct and can be improved through training (Mathisen, Bronnick, 2009).

A body of research supports the relationship between psychological capital and creative self-efficacy. PsyCap has been found to facilitate creativity (Tierney, Farmer, 2002); indicating sustainable success (Tang, 2020a), enhancing its cognitive pathways to facilitate creative thinking and plays a part in creative performance (Sweetman et al., 2011). Despite scientific progress, these relationships are considered to be understudied (Taştan, 2016). Consequently, it is expected that there would be strong relationships between PsyCap with creative self-efficacy, and future entrepreneurs would possess it to pursue future ventures.

\section{Background for research}

As seen above, the growing body of evidence in separate aforementioned constructs is promising however little has yet been done in the field of conjoining psychological capital, creative self-efficacy, and future entrepreneurs. Thus, this research aims to provide some valuable contribution to the area. As creativity could potentially extend the PsyCap construct (Luthans, Youssef et al., 2007), there was an aim to investigate whether Entrepreneurship Academy students might demonstrate creative self-efficacy's links with PsyCap. Vytautas Magnus University Centre for Enterprise Practices (Lithuania) delivers an experiential entrepreneurship education program using a range of innovative methods, where teamwork and creative activities are foremost, with some focus on promoting personal growth. At university, the courses are delivered as a part of the minor study program "Entrepreneurship Academy". The centre collaborates with around 80 companies and 30 lecturers and delivers the programme for approx. 300 students annually (Kyguolienè, Švipas, 2019). The Academy programme provides education and practices around creativity and creative self-efficacy via the Design Thinking method, and various opportunities to enhance PsyCap and its components via a wide range of personal responsibilities within teamwork, real-life entrepreneurship challenges, reflections in case of setbacks, a celebration of strengths, teamwork and mentors' feedback. PsyCap could be one of the essential elements in the development of future ventures or sustaining current ones, thus it is beneficial to investigate whether Entrepreneurship soon-to-be graduates own more PsyCap resources than their young counterparts. As the majority of them already either work or 
work and study, own or intend to own business, this cohort's results might offer some other valuable insights.

\section{Methods}

\section{Participants}

In this pilot study, 43 participants (18-25 years old) were voluntarily recruited to take part in this research $(34.9 \%$ (15) male, $65.1 \%$ (28) female). The respondents of the study were students who participated in an experiential entrepreneurship education program for at least 6 months to 1,5 years and are either working in different companies, have established their business, or still studying.

\section{Measures}

Psychological Capital. PsyCap was evaluated using the PCQ-24 (Luthans, Youssef et al., 2007) which is a higher-order construct that consists of four subscales (selfefficacy, hope, resilience, and optimism) each comprised of six items for a total of 24 items. All items were measured using a 6-point Likert scale of agreement with response options ranging from 1 (strongly disagree) to 6 (strongly agree). In the present study, Cronbach $\alpha=.75$ for the PsyCap scale, and Cronbach for subscales varies greatly: self-efficacy $\alpha=.68$, hope, $\alpha=.703$, resilience $\alpha=.45$, and optimism $\alpha=.33$. During analysis, low resilience and optimism scale reliability results were taken under consideration, hence it either will not be reported or if mentioned it has to be taken reservedly.
This occurrence has been consistent with the wider research, as internal consistency reliability for optimism and resilience tends to be consistently lower than those reported for self-efficacy and hope. It might be the presence of reverse-scored items in the optimism and resilience subscales, as such items can reduce scale reliability (Dawkins et al., 2013). However, as the overall PsyCap was found to forecast performance better than individual components (Luthans, Youssef, 2007), for the research the overall scale is the most important, additionally exploring separate scales. The questions range for self-efficacy: "I feel confident analysing a long-term problem to find a solution"; hope: "there are lots of ways around any problem", resilience: "I can get through difficult times at work because I've experienced difficulty before", and optimism: "I'm optimistic about what will happen to me in the future as it pertains to work".

Creative self-efficacy was measured with three items based on the creative selfefficacy scale and has been used to assess employee perceived capacity for creative work (Tierney, Farmer, 2002). Reliability Cronbach $\alpha=.77$. All items were rated on a six-point scale ranging from 1 (strongly disagree) to 6 (strongly agree). A sample item is "I have confidence in my ability to solve problems creatively. Both questionnaires were provided in the Lithuanian language.

\section{Procedure}

The majority (40) of questionnaires were completed in the hall (as a part of a wider event programme) and administered by one of the programme leaders. 
Participants filled the PsyCap and creative self-efficacy questionnaires via Google survey forms. The remaining three participants have filled the form via the invitation within the programme graduates' social media group. All data were collected during a period of a week. The representative young people sample PsyCap scores were obtained from the scientific study conducted by Mykolas Romeris University (Rakauskienè et al., 2015, 2017).

\section{Data analysis}

The statistical package SPSS 17.0 was used for data analysis. Because some of the data was non-normally distributed (see Table 1), both parametric and nonparametric statistics were used. The means of PsyCap were compared using parametric tests ( $\mathrm{t}$-test or ANOVA), whereas self-efficacy, hope, and creative self-efficacy were compared using non-parametric tests (Mann-Whitney or Kruskal-Wallis tests).

As can be seen in Table 1, the ShapiroWilk test indicates that hope, and creative self-efficacy data in those scales are not normally distributed. Hence, nonparametric tests will be used to analyse the data from those scales. Representative Sample all scales have met the normal data distribution assumptions: PsyCap $p=.816$, self-efficacy $p=.057$, hope $p=$ 069.

\section{Results}

Table 2 presents descriptive analysis (means and standard deviations) of study variables.

Table 1. The Entrepreneurship Academy students' data distribution (Shapiro-Wilk Test of Normality), $n=43$

\begin{tabular}{|l|c|c|c|c|c|}
\hline Variables & Skewness & SE & Kurtosis & SE & p value $^{*}$ \\
\hline PsyCap & -.325 & .361 & -.726 & .709 & .132 \\
\hline Self-efficacy & .014 & .361 & -.439 & .709 & .103 \\
\hline Hope & -.832 & .361 & -.434 & .709 & $.023^{*}$ \\
\hline Creative self-efficacy & -.724 & .361 & -.345 & .709 & $.014^{*}$ \\
\hline
\end{tabular}

Note: $\mathrm{SE}$ - standard error, ${ }^{*} \mathrm{p}$ value of Shapiro-Wilk test

Table 2. Means and standard deviations of the PsyCap, self-efficacy, hope, and creative self-efficacy

\begin{tabular}{|l|c|c|}
\hline Variables & Mean & Standard Deviation \\
\hline PsyCap & 106.74 & 9.7 \\
\hline Self-efficacy & 28.09 & 3.6 \\
\hline Hope & 28.81 & 3.89 \\
\hline Creative self-efficacy & 14.23 & 2.48 \\
\hline
\end{tabular}


Table 3. PsyCap and its subscales inter-relationships correlation coefficients

\begin{tabular}{|l|c|c|c|c|}
\hline Variables & Self-efficacy & Hope & Resilience & Optimism \\
\hline PsyCap & $.713^{* *}$ & $.744^{* *}$ & $.789^{* *}$ & $.457^{\star *}$ \\
\hline Self-efficacy & & $.408^{\star *}$ & $.532^{* *}$ & -.03 \\
\hline Hope & & & $.474^{* *}$ & .153 \\
\hline Resilience & & & & .119 \\
\hline
\end{tabular}

Note: ${ }^{* *} \mathrm{p}<.01$

\section{Scales correlations}

One of the aims of this research was to investigate the relationship between creative self-efficacy and PsyCap (self-efficacy, hope, resilience, and optimism). The relationship between PsyCap and its subscales with creative self-efficacy was evaluated using Spearman rho coefficient because creative self-efficacy does not present normal data distribution.

Spearman's rho Correlation Coefficient revealed only marginally significant correlation between creative self-efficacy and self-efficacy rs $(42)=.29, \mathrm{p}=.055$, but did not with PsyCap rs $(42)=.25, \mathrm{p}=.11$, or hope rs $(42)=.18, \mathrm{p}=.26$.

Table 3 presents PsyCap and its subscales inter-relationships. A Pearson correlation coefficient was used to determine whether PsyCap, self-efficacy, and optimism relationships are statistically significant, and a Spearman's rho Correlation Coefficient to explore hope and resilience relationships because they did not meet normal data distribution assumptions.

As seen in Table 3, All PsyCap with its subscales correlations are significant: self-efficacy $\mathrm{r}(42)=.71, \mathrm{p}<.001$; optimism $\mathrm{r}(42)=.46, \mathrm{p}=.002$; hope $\mathrm{rs}(42)=$ $.74, \mathrm{p}<.001$; resilience $\mathrm{rs}(42)=.79, \mathrm{p}<$ .001. The PsyCap scale relationship with optimism scale is significant but weaker $\mathrm{r}(42)=.46, \mathrm{p}=.002$. The other scales that have significant relationships are selfefficacy and hope rs $(42)=.41, \mathrm{p}=.007$; self-efficacy and resilience rs $(42)=.53, \mathrm{p}$ $<.001$; hope and resilience $\rho(42)=.47$, $\mathrm{p}=.001$. Correlations between optimism scale and other scales are not significant. There is a negative but not significant relationship with self-efficacy $\mathrm{r}(42)=-.03$, $\mathrm{p}=.85$, hope $\mathrm{rs}(42)=.15, \mathrm{p}=.33$; resilience $\mathrm{rs}(42)=.12, \mathrm{p}=.45$. Consequently, the PsyCap scales indicate significant relations with all its subscales, but the scale of optimism does not have a significant relationship with other scales. Also, there is no statistical relationship with creative self-efficacy, where only marginally significant trending is observed in the predicted direction between self-efficacy and creative self-efficacy.

\section{Comparing the Entrepreneurship Academy students' scales with a representational sample of young people}

It was also aimed to explore whether there is a significant difference in means between PsyCap and its components comparing Entrepreneurship Academy students scales with a representational sample of young people (age $\leq 25$ ) (Rakauskienè et al., 2015, 2017). The predictions would be that Entrepreneurship 
Academy participants have significantly higher PsyCap scales than the general population.

The Entrepreneurship Academy students' group (43) PsyCap is $\mathrm{M}=106.74$ $(\mathrm{SD}=9.7)$. By comparison, the representative sample of young people (93) PsyCap mean was numerically smaller $(\mathrm{M}=98.47$, $\mathrm{SD}=13.01)$. To test the hypothesis that academy students and a representative sample of young people were associated with statistically significant different PsyCap means, an independent two samples t-test was performed. Students and young people's PsyCap distributions were sufficiently normal for purposes of conducting a t-test. Additionally, the assumptions of homogeneity of variances were tested and satisfied via Levene's F test, $F(134)=3.08$, $p=.081$.The independent samples t-test was associated with a statistically significant effect $t(134)=3.7, p<.001, d=0.72$. Thus, the Academy students had a statistically significantly higher PsyCap means than a representative group, and the effect size is higher than medium, based on guidelines (Cohen, 1988).

The students' group self-efficacy assumptions of homogeneity of variances were tested and not satisfied via parametric test Levene's F, $F(134)=4.11, p=.045$. When tested with non-parametric Levene's test of Homogeneity of Variance, based on Median, Levene's test F, $F(134)=3.79, p=$ .054. Thus, a Man-Whitney U Test could be performed to compare Self-efficacy medians. A Mann-Whitney test indicated, that the Academy participants ( $\mathrm{Mdn}=28)$ have statistically significantly higher selfefficacy scores than a representative group of young people $(\mathrm{Mdn}=26), U=1361, p=$ $.003, r=.26$.
As students' group hope scale did not meet normal data distribution, Homogeneity of Variance was tested with nonparametric Levene's test based on Median, $F(134)=1.223, p=.27$. Thus, the ManWhitney U Test was performed to compare hope medians. The test indicated, that the Academy students (Mdn = 30) have statistically significantly higher hope scores than a representative group of young people $(\mathrm{Mdn}=25) U=1016, p<.001, r=.4$.

Just to mention, that the Academy students (Mdn = 28) had statistically significantly higher resilience scores than a representative group of young people $(\mathrm{Mdn}=$ 24) $U=1064, p<.001$, but the optimism scale independent samples t-test was not associated with a statistically significant effect $t(134)=-1.811, p=.072$. However, these two scores have to be considered with caution, as their Cronbach alpha scores were lower than required.

The test results indicate that Academy students have significantly higher PsyCap scores and its subscales of self-efficacy, and hope than a representative group of young people.

\section{Working or studying students vs. working and studying students}

One of the aims was to analyse how psychological capital, its subscales and creative self-efficacy are different across those who study and work, or both combined. The hypothesis would be that working and studying students would have higher PsyCap and its subscales groups. In this research sample, 39.5\% (17) of participants are studying, 41.9\% (18) working and studying, and 8 of them only working $18.6 \%(8)$. 
An ANOVA was used to compare PsyCap scales between the groups of only working, only studying and working and studying participants. A test reveals $F(2$, 40) $=0.939, p=.399, \eta_{p}^{2}=.045$ that there are no significant differences in means across the groups.

An ANOVA was used to compare selfefficacy scales between the same groups, and homogeneity of variance assumptions was met: Levene's test F, $F(2,40)=.545, p=$ $.58)$. A test reveals $F(2,40)=0.079, p=$ $.138, \eta_{p}^{2}=.094$, and we can see that there are no significant differences in means across the groups. But if we grouped the students into work or study and measured against working and studying at the same time, we could see an interesting tendency. Normal distribution assumptions and Levene's test $(F(2,40)=1.057, p=.310)$ allowed to conduct t-test to compare selfefficacy scales between two groups: those who study or work, and who do both, $t=$ -1.984, $p=.054, d=.54$ (medium-size effect). Thus, we can say, that those who work and study have marginally significant higher self-efficacy scores with a medium-size effect, and more participants would be needed to test the tendency.

Hope scales homogeneity of variance were met by non-parametric Levene's test based on median $F(2,40)=2.157, p=$ .129 , thus we compared medians using Kruskal-Wallis test with results $H(2)=$ $8.0, p=.018$. We see significant differences in groups with a mean rank for studying participants 16.97, a mean rank for working and studying participants 28.31, and a mean rank 18.50 for working participants. Moreover, if we combine working or studying participants together and compare the medians with working and studying participants, we see that working and studying participants have significantly higher hope scales medians than the other two groups combined in the scale of hope, $U=111.5, p=.005, r=0.44$.

Also, there were no significant differences in creative self-efficacy $H(2)=1.826$, $p=.401$. Even when combined into two groups ("work or study" and "work and study"), there were no significant differences either: creative self-efficacy $U=$ 192.5, $p=.419, r=0.12$.

Thus, we can say, that those who work and study have statistically significantly higher hope scores than the other two groups combines and marginally significant higher self-efficacy scores with medium-size effect, but more participants would be needed to test the tendency.

\section{PsyCap, creative self-efficacy and entrepreneurship}

In this research 9.3\% (4) participants already own a business, $67.4 \%$ (29) would like to create one, $4.7 \%$ (2) not intending to own a business and $18.6 \%$ (8) of them do not know yet. The hypothesis is that business owners or those intending to own it at some point would have higher PsyCap and its subscales scores.

A one-way between-subjects ANOVA was conducted to compare PsyCap scores, and there was a significant difference between means $F(3,39)=3.56, p=.023$, $\eta_{p}{ }^{2}=.215$. Post Hoc comparisons using the Games-Howell test (as it can handle different group numbers) indicated that the mean scores for not intending to own a business $(\mathrm{M}=92, \mathrm{SD}=2.83)$ was significantly lower from other three groups: 
between the business owners $(M=115.25$, SD 7.27), $p=.017$, intending to create business $(\mathrm{M}=105.66, \mathrm{SD}=9.9) p=.017$, or undecided participants $(\mathrm{M}=110.13, \mathrm{SD}=$ 4.97) $p=.021$ PsyCap scales means.

Comparing self-efficacy scale scores (Levene's test $\mathrm{F}(3,39)=1.658, p=.192$ ) using an ANOVA, there were no significant differences between means $F(3,39)=$ $1.899, p=.146, \eta_{p}^{2}=.127$. Post Hoc GamesHowell test indicates that those who do not intend to create business have statistically lower means $(\mathrm{M}=22.50, \mathrm{SD}=707)$ between business owners $(\mathrm{M}=29.25, \mathrm{SD}=$ 1.89), $p=.011$, those who would like to create business $(\mathrm{M}=28.31, \mathrm{SD}=3.67) p=$ .013 , and those who do not intend $(\mathrm{M}=$ 22.50, SD .707), $p=.001$.

A Kruskal-Wallis test has been conducted to compare mean ranks in hope and creative self-efficacy scales. There were no significant differences observed among the mean ranks of hope $H(3)=5.53, p=$ .137 or creative self-efficacy $H(3)=3.61$, $p=.307$.

Hence, comparing the groups that indicate various levels of entrepreneurship or the intention to get involved in the future, those who own business, who intend to own or those who are undecided yet have significantly higher PsyCap than those who do not intend to have a business. There are no statistically significant differences among the other three groups. Also, the scale of self-efficacy of non-intending to own business participants have statistically significant lower scores than the other three groups. Just to mention, as expected there were no statistically significant differences between males and females across scales of PsyCap and creative self-efficacy.

\section{Discussion}

The purpose of the study was to explore whether the students who have undergone the entrepreneurship programme have higher PsyCap resources than the population who share similar age. Alongside, as the programme offers many opportunities to develop creativity, it was meaningful to investigate whether PsyCap may correlate with students' creative self-efficacy. Additionally, it was explored how their working experience and entrepreneurship intentions may relate to PsyCap and creative self-efficacy. As insufficient empirical studies have investigated positive psychological capital on future entrepreneurs (Hizam-Hanafiah et al., 2017), this research aims to offer a valuable contribution to the field.

Firstly, in the research, the reliability for separate subscales was lower than the overall PsyCap. Even though there was a significant correlation between PsyCap and its four components, the optimism subscale neither indicated reliability nor it had statistically significant correlations with other subscales. As F. Luthans et al. (2007) noticed, overall PsyCap was found to have a synergistic effect and it may be greater than the sum of its parts (Luthans, Avolio et al., 2007). S. Hobfoll's (2002) psychological resource theory considers psychological constructs to be of a wider dominion (Hobfoll, 2002), which primes the explication that each component of PsyCap enables cognitive and motivational resources to merge and allow more profound outcomes (Luthans, Avolio et al., 2007). 


\section{Entrepreneurship academy students PsyCap and its scales}

PsyCap presents as a malleable construct (Luthans, Avolio et al., 2007, Luthans et al., 2010) and can be propagated even via relatively short training interventions (Luthans, Avey, et al., 2006), thus correlations could be explored, though no definite conclusions could be drawn about its causational effects as no test-retest studies were performed, and the assumption cannot be omitted, that students prior to the programme maintained higher PsyCap resources.

This study confirms students' PsyCap, self-efficacy, hope, (and resilience, but not optimism) resources were higher than a representative group of young people. To relate to it, the programme had a wide range of opportunities to develop particularly the aspect of self-efficacy and hope. Students had to learn to work individually with perseverance to contribute to the teamwork and they needed to present their ideas to the organisations, whose cases they were improving or solving, and mastery experiences or performance attainments could be one of the ways to develop those particular subscales (Luthans et al., 2004). Self-efficacy is considered malleable (Bandura, 1977; Gist, Mitchell, 1992), and some empirical evidence support this notion (Tierney, Farmer, 2011). There is also some evidence that hope - will- power (agency) and way-power (pathways) (Snyder et al., 1991) - can be developed (Luthans et al., 2004). During the programme, they had a range of opportunities to learn to design pathways (e.g. series of prototypes) that lead towards desired goals, and in case of setbacks, they learned to produce more strategies to attain them.

During the entrepreneurship programme, the students were able to observe how both their peers and facilitators, cope with problems and model their behaviour. F. Luthans (2004) identifies it as vicarious experiences or modelling. A. Bandura notes (1999), "if people see others like themselves succeed by sustained effort, they come to believe that they, too, have the capacity to succeed." (as cited in Luthans et al., 2004). If the models are related in age, physical characteristics and experience, and the appropriate task is assigned, the more it will influence positively the PsyCap (Luthans et al., 2004). Moreover, the mentors were supporting the participants to appreciate their strengths, providing factual positive feedback about their capabilities. This social persuasion aspect could be correlated with how people see themselves (Luthans et al., 2004; Luthans, Youssef et al., 2007)

Interestingly, physiological and psychological arousals may influence PsyCap (Luthans et al., 2004). During the spring term of the university programme, the pandemic of COVID-19 occurred, when societies worldwide have experienced an unprecedented shockwave which created an economic situation that has no familiar and predictable parallel in the entrepreneurship literature (Kuckertz et al., 2020). The forecast of potential economic adversity could have had an effect on optimism results as the helplessness model suggests that after experiencing uncontrollable unfavourable events, people may perceive their efforts inept (Peterson, Steen, 2002). Grim economic prospects might be projected as more permanent and harder to control. On the other hand, optimism and 
resilience might not necessarily have positive relationships with the growth intention of entrepreneurs (Hizam-Hanafiah et al., 2017) and some components may have significant relations to PsyCap but not others (Youssef, Luthans, 2007). Therefore, the complexity of the results and sufficiently unanswered inquiries are thought-provoking and only pleads for more research in the field.

\section{PsyCap and creative self-efficacy relationship}

Creativity was considered as one of the potential extensions of PsyCap (Luthans, Youssef et al., 2007), instigating to select the related construct of creative self-efficacy as it has been found, that by increasing the plasticity of the cognitive scope to be creative, in turn, increases the actual creativity (Royston, Reiter-Palmon, 2019), and creative self-efficacy is an important antecedent for creative effort and performance (Mathisen, Bronnick, 2009; Sweetman et al., 2011; Rego et al., 2012; Chen, Zhang, 2019). Surprisingly, no significant relationship was found between PsyCap and creative self-efficacy, where only marginally significant trending is observed in the predicted direction between self-efficacy and creative self-efficacy. The latter confirms the tendency explored by other research where self-rated creativity correlated with self-efficacy (Haase et al., 2018). Ample literature exposes that some research begins to question the validity of the self-perceptions of creativity. Even with the Design Thinking extensive training (similar to this research students' experience), the research has found that retest may not necessarily indicate the rise of creative self-efficacy (Ohly et al., 2016). As mentioned before, some studies established a correlation between creative self-beliefs and performance, yet others found participants' self-beliefs about their creativity may not produce more creative outcomes. Moreover, even in the studies showing a positive relationship between self-perception and performance, the effect is moderate (Pretz, Nelson, 2017), its outcomes are not necessarily consistent across contexts (Sweetman et al., 2011), and it might be more influential in studies conducted in the United States than elsewhere (Luthans, Youssef-Morgan, 2017). The study was conducted in Lithuania where culturally may still be difficult to accurately and comfortably identify creative efficacy.

\section{PsyCap, entrepreneurship and work}

In the research, those who work and study have higher hope resources than studying or working groups combined, and marginally significant higher self-efficacy scores with medium-size effect. To draw definite conclusions, more research is needed to explore the tendency. However, those who work and study may have more opportunities to test their capacity to solve the problems and to come up with multiple pathways to reach their goals. The entrepreneurship aspect revealed that groups indicating ownership of a business, intention to create one, or even undecided, have significantly higher PsyCap and self-efficacy resources than those who do not intend to own a business. This tendency needs to be explored with higher numbers. Otherwise, it is promising because empirical evidence provides 
that there is an interaction between PsyCap and entrepreneurial success (Fu et al., 2008, as cited in Ma et al., 2018), and psychological capital can serve as a profound resource for entrepreneurs in developing motivation to pursue their ventures in the future (Hizam-Hanafiah et al., 2017).

\section{Conclusions, limitations and future implications}

This research makes several contributions. The results of the study revealed that students who have undergone the Entrepreneurship Academy programme have shown higher overall PsyCap results comparing to the representative sample of young people. Based on the literature, it has been anticipated that creative self-efficacy may have correlations with PsyCap, however, this research could not confirm that. Working and studying participants indicated higher levels of two PsyCap scales: hope and self-efficacy. Those who are already engaged in entrepreneurship, those who intend to pursue entrepreneurship avenues and even if yet undecided about whether they intend to create a business in the future indicate higher PsyCap resources than those who do not intend to do so. The higher results hopefully help them to build new ventures in the future amidst unprecedented times.

As with any empirical study, there are methodological limitations that need to be recognised. Firstly, no causal conclusions can be drawn as neither experimental manipulation nor random assignment was part of the study design, so higher PsyCap resources could not be assigned solely to the Academy programme.
Testing students at the beginning and the end of the study would have produced more accurate results. Having a current (rather than retrospective) randomised student (rather than young people) group would help to gain a diverse perspective and draw firmer conclusions.

Also, Cronbach's alpha for two PsyCap subscales were $<.70$. Thus, the reliability of the scale should be tested in the future. Besides, the analysis was focused on one limited-size group of individuals, therefore, the generalizability of the findings is limited. Whether the findings could be extended to different age or culture groups remains to be tested in future research. Also, creative self-efficacy has been chosen as a desirable construct for this study, however, to explore PsyCap and its relation to creativity, other measurements could be considered to establish whether this element is a commendable potential component for PsyCap.

Future research may help to enhance the understanding of the versatility of the construct. Nevertheless, the results obtained in this study may have important practical implications: psychological capital could have a significant place in entrepreneurship education, and academic business and management curriculum could consider adding suitable agenda and appropriate activities to improve psychological resources, that have been found to be important for future entrepreneurs in the wider literature. Considering creative self-efficacy, it is worth testing whether actual creativity and creative self-efficacy have correlations. To promote awareness of creative self-efficacy distinct activities may be needed to be designed. 


\section{References}

1. Avey, J. B., Luthans, F., Youssef, C. M. (2009). The Additive Value of Positive Psychological Capital in Predicting Work Attitudes and Behaviors // Journal of Management. Vol. 36(2), pp. 430-452. doi: 10.1177/0149206308329961

2. Bandura, A. (1977). Self-efficacy: Toward a Unifying Theory of Behavioral Change // Psychological Review. Vol. 84(2), pp. 191-215. doi: 10.1037/0033-295X.84.2.191

3. Cameron, K., Caza, A. (2004). Introduction: Contributions to the Discipline of Positive Organizational Scholarship // American Behavioral Scientist. Vol. 47, pp. 731-739. doi: 0.1177/0002764203260207

4. Carvier, C. S., Scheier, M. F. (2002). Optimism / In C. R. Snyder \& S. J. Lopez (Eds.), Handbook of Positive Psychology (pp. 231-243). - New York: Oxford University Press

5. Cavus, M., Kapusuz, A. (2015). Psychological Capital: Definition, Components and Effects // British Journal of Education, Society \& Behavioural Science. Vol. 5, pp. 244-255. doi: 10.9734/BJESBS/2015/12574

6. Chen, Y., Zhang, L. (2019). Be Creative as Proactive? The Impact of Creative Self-efficacy on Employee Creativity: A Proactive Perspective // Current Psychology. Vol. 38(2), pp. 589-598. doi: 10.1007/s12144-017-9721-6

7. Cohen, J. (1988). Statistical Power Analysis for the Behavioural Sciences (2nd ed.). - Routledge.

8. Dawkins, S., Martin, A., Scott, J., Sanderson, K. (2013). Building on the Positives: A Psychometric Review and Critical Analysis of the Construct of Psychological Capital // Journal of Occupational and Organizational Psychology. Vol. 86(3), pp. 348-370. doi: 10.1111/joop.12007

9. Fillis, I., Rentschler, R. (2010). The Role of Creativity in Entrepreneurship // Journal of Enterprising Culture (JEC). Vol. 18, pp. 49-81. doi: 10.1142/S0218495810000501

10. Gist, M. E., Mitchell, T. B. (1992). Self-efficacy: A Theoretical Analysis of its Determinants and Malleability // Academy of Management Review. Vol. 17(2), pp. 183-211. doi: 10.0.21.89/ AMR.1992.4279530

11. Gong, Y., Huang, J.-C., Farh, J.-L. (2009). Employee Learning Orientation, Transformational Leadership, and Employee Creativity: The Mediating Role of Employee
Creative Self-efficacy // Academy of Management Journal. Vol. 52(4), pp. 765-778. doi: 10.0.21.89/AMJ.2009.43670890

12. Haase, J., Hoff, E. V, Hanel, P. H. P., Innes-Ker, Å. (2018). A Meta-Analysis of the Relation between Creative Self-efficacy and Different Creativity Measurements // Creativity Research Journal. Vol. 30(1), pp. 1-16. doi: 10.1080/10400419.2018.1411436

13. Harms, P., Luthans, F. (2012). Measuring Implicit Psychological Constructs in Organizational Behavior: An Example using Psychological Capital // Journal of Organizational Behavior. Vol. 33. doi: 10.1002/job.1785

14. Hasan, M., Hatidja, S., Nurjanna, Guampe, F. A., Gempita, Ma'ruf, M. I. (2019). Entrepreneurship Learning, Positive Psychological Capital and Entrepreneur Competence of Students: A research study // Entrepreneurship and Sustainability Issues. Vol.7(1), pp. 425-437. doi: 10.9770/jesi.2019.7.1(30)

15. Hizam-Hanafiah, M., Yousaf, S. U., Usman, B. (2017). The Influence of Psychological Capital on the Growth Intentions of Entrepreneurs: A Study on Malaysian SME Entrepreneurs // Business \& Economic Horizons. Vol. 13(5), pp. 556-569. doi: 10.0.59.104/beh.2017.38

16. Hmieleski, K. M., Baron, R. A. (2009). Entrepreneurs' Optimism and New Venture Performance: A Social Cognitive Perspective // Academy of Management Journal. Vol. 52(3), pp. 473-488. doi: 10.0.21.89/ AMJ.2009.41330755

17. Hmieleski, K. M., Carr, J. C., Baron, R. A. (2015). Integrating Discovery and Creation Perspectives of Entrepreneurial Action: The Relative Roles of Founding CEO Human Capital, Social Capital, and Psychological Capital in Contexts of Risk versus Uncertainty // Strategic Entrepreneurship Journal. Vol. 9(4), pp. 289-312. doi: 10.0.3.234/sej.1208

18. Hobfoll, S. (2002). Social and Psychological Resources and Adaptation // Review of General Psychology. Vol. 6, pp. 307-324. doi: 10.1037/1089-2680.6.4.307

19. Hsu, M. L., Hou, S.-T., Fan, H.-L. (2011). Creative Self-efficacy and Innovative Behavior in a Service Setting: Optimism as a Moderator // The Journal of Creative Behavior. Vol. 45(4), pp. 258-272. doi: 10.1002/j.2162-6057.2011. tb01430.x 
20. Hsu, S.-H., Wang, Y.-C., Chen, Y.-F., DahlgaardPark, S. M. (2014). Building Business Excellence through Psychological Capital // Total Quality Management \& Business Excellence. Vol. 25(11-12), pp. 1210-1223. doi: 10.1080/14783363.2014.913349

21. Jensen, S. M., Luthans, F. (2006). Relationship between Entrepreneurs' Psychological Capital and their Authentic Leadership // Journal of Managerial Issues. Vol. 18(2), pp. 254-273. doi: $10.2307 / 40604537$

22. Jiang, W., Gu, Q. (2017). Leader Creativity Expectations Motivate Employee Creativity: A Moderated Mediation Examination // International Journal of Human Resource Management. Vol. 28(5), pp. 724-749. doi: 10.0.4.56/09585192.2015.1109535

23. Karwowski, M. (2016). The Dynamics of Creative Self-Concept: Changes and Reciprocal Relations Between Creative Self-Efficacy and Creative Personal Identity // Creativity Research Journal. Vol. 28(1), pp. 99-104. doi: 10.0.4.56/10400419.2016.1125254

24. Kuckertz, A., Brändle, L., Gaudig, A., Hinderer, S., Morales Reyes, C. A., Prochotta, A., Steinbrink, K. M., Berger, E. S. C. (2020). Startups in Times of Crisis - A Rapid Response to the COVID-19 Pandemic // Journal of Business Venturing Insights. Vol. 13, pp. e00169-e00169. doi: 10.1016/j.jbvi.2020.e00169

25. Kyguolienè, A., Švipas, L. (2019). Personal Entrepreneurial Competencies of Participants in Experiential Entrepreneurship Education // Management of Organizations: Systematic Research. Vol. 82(1), pp. 37-51. doi: 10.1515/ mosr-2019-0012

26. Li, C.-R., Yang, Y., Lin, C.-J., Xu, Y. (2020). Within-person Relationship between Creative Self-efficacy and Individual Creativity: The Mediator of Creative Process Engagement and the Moderator of Regulatory Focus // The Journal of Creative Behavior. doi: 10.1002/ jocb.435

27. Liu, D., Jiang, K., Shalley, C. E., Keem, S., Zhou, J. (2016). Motivational Mechanisms of Employee Creativity: A Meta-analytic Examination and Theoretical Extension of the Creativity Literature // Organizational Behavior and Human Decision Processes. Vol. 137, pp. 236-263. doi: 10.1016/j.obhdp.2016.08.001

28. Luthans, F. (2002). The Need for and Meaning of Positive Organizational Behavior // Journal of Organizational Behavior. Vol. 23(6), pp. 695706. doi: 10.0.3.234/job.165

29. Luthans, F., Avey, J. B., Avolio, B. J., Norman, S. M., Combs, G. M. (2006). Psychological Capital Development: Toward a Micro-intervention // Journal of Organizational Behavior. Vol. 27(3), pp. 387-393. doi: $10.2307 / 4093934$

30. Luthans, F., Avey, J. B., Avolio, B. J., Peterson, S. J. (2010). The Development and Resulting Performance Impact of Positive Psychological Capital // Human Resource Development Quarterly. Vol. 21(1), pp. 41-67. doi: 10.1002/ hrdq. 20034

31. Luthans, F., Avey, J., Clapp-Smith, R., Li, W. (2008). More Evidence on the Value of Chinese Workers' Psychological Capital // International Journal of Human Resource Management. Vol. 19, pp. 818-827. doi: 10.1080/09585190801991194

32. Luthans, F., Avolio, B. J., Avey, J. B., Norman, S. M. (2007). Positive Psychological Capital: Measurement and Relationship with Performance and Satisfaction // Personnel Psychology. Vol. 60, Issue 3, pp. 541-572. doi: 10.1111/j.1744-6570.2007.00083.x

33. Luthans, F., Church, A. H. (2002). Positive organizational Behavior: Developing and Managing Psychological Strengths // Academy of Management Executive. Vol. 16(1), pp. 5772. doi: 10.0.21.89/AME.2002.6640181

34. Luthans, F., Luthans, K. W., Luthans, B. C. (2004). Positive Psychological Capital: Beyond Human and Social Capital // Business Horizons. Vol. 47(1), pp. 45-50. doi: 10.1016/j. bushor.2003.11.007

35. Luthans, F., Vogelgesang, G., Lester, P. (2006). Developing the Psychological Capital of Resiliency // Human Resource Development Review. Vol. 5, pp. 25-44. doi: $0.1177 / 1534484305285335$

36. Luthans, F., Youssef-Morgan, C. M. (2017). Psychological Capital: An Evidence-based Positive Approach // Annual Review of Organizational Psychology and Organizational Behavior. Vol. 4(1), pp. 339-366. doi: 10.1146/ annurev-orgpsych-032516-113324

37. Luthans, F., Youssef, C. M. (2007). Emerging Positive Organizational Behavior // Journal of Management. Vol. 33(3), pp. 321-349. doi: 10.0.4.153/0149206307300814

38. Luthans, F., Youssef, C. M., Avolio, B. J. (2007). Psychological Capital: Developing the Human 
Competitive Edge / In Psychological Capital: Developing the Human Competitive Edge. doi: 10.1093/acprof:oso/9780195187526.001.0001

39. Ma, H., Barbe, F. T., Zhang, Y. C. (2018). Can Social Capital and Psychological Capital Improve the Entrepreneurial Performance of the New Generation of Migrant Workers in China? // Sustainability (Switzerland). Vol. 10(11), p. 3964. doi: 10.3390/su10113964

40. Mathisen, G. E., Bronnick, K. S. (2009). Creative Self-efficacy: An Intervention Study // International Journal of Educational Research. Vol. 48 (1), pp. $21-29$. doi: $10.1016 /$ j. ijer.2009.02.009

41. Newman, A., Ucbasaran, D., Zhu, F., Hirst, G. (2014). Psychological Capital: A Review and Synthesis // Journal of Organizational Behavior. Vol. 35(S1), pp. S120-S138. doi: 10.1002/ job. 1916

42. Nicola, M., Alsafi, Z., Sohrabi, C., Kerwan, A., Al-Jabir, A., Iosifidis, C., Agha, M., Agha, R. (2020). The Socio-economic Implications of the Coronavirus Pandemic (COVID-19): A Review // International Journal of Surgery. Vol. 78, pp. 185-193. doi: 10.1016/j.ijsu.2020.04.018

43. Ohly, S., Plückthun, L., Kissel, D. (2016). Developing Students' Creative Self-efficacy Based on Design-Thinking: Evaluation of an Elective University Course // Psychology Learning \& Teaching. Vol. 16(1), pp. 125-132. doi: $10.1177 / 1475725716681714$

44. Pease, P., Cunningham, J. (2016). Entrepreneurial Psychological Capital: A Different Way of Understanding Entrepreneurial Capacity. British Academy of Management Conference: Thriving in Turbulent Times (BAM 2016) 4th - 8th September. Internet access: <https:// core.ac.uk/download/pdf/78074477.pdf>, [Accessed: July 01, 2020].

45. Peterson, C., Steen, T. A. (2002). Optimistic Explanatory Style / In C. R. Snyder \& S. J. Lopez (Eds.), Handbook of Positive Psychology (pp. 244-256). - New York: Oxford University Press.

46. Pretz, J. E., Nelson, D. (2017). Creativity is Influenced by Domain, Creative Self-efficacy, Mindset, Self-efficacy, and Self-esteem / In M. Karwowski \& J. C. B. T.-T. C. S. Kaufman (Eds.), Explorations in Creativity Research (pp. 155-170). Academic Press. doi: 10.1016/ B978-0-12-809790-8.00009-1

47. Rakauskienė, O. G., Puškorius, S., Diržyte, A., Servetkienè, V., Krinickienè, E., Bartuševičienė, I.,
Volodzkienè, L., Juršènienė, V., Kisielytė, U. (2017). Socialinė ekonominè nelygybė Lietuvoje: Mokslo studija. - Vilnius: Mykolo Romerio universitetas.

48. Rakauskienè, O. G., Servetkienè, V., Puškorius, S., Čaplinskienè, M., Diržytè, A., Ranceva, O., Bilevičienė, T., Kazlauskienė, E., Žitkienė, R., Štreimikienė, D., Monkevičius, A., Bieliauskienè, R., Laurinavičius, A., Krinickienè, E. (2015). Gyvenimo kokybès matavimo rodiklių sistema ir vertinimo modelis: mokslo studija. - Vilnius: Mykolo Romerio universitetas.

49. Rego, A., Sousa, F., Marques, C., Cunha, M. P. E. (2012). Retail Employees' Self-efficacy and Hope Predicting their Positive Affect and Creativity // European Journal of Work and Organizational Psychology. Vol. 21(6), pp. 923-945. doi: 10.1080/1359432X.2011.610891

50. Royston, R., Reiter-Palmon, R. (2019). Creative Self-efficacy as Mediator between Creative Mindsets and Creative Problem-solving // The Journal of Creative Behavior. Vol. 53(4), pp. 472-481. doi: 10.1002/jocb.226

51. Seligman, M. E. P., Csikszentmihalyi, M. (2000). Positive Psychology: An Introduction // American Psychologist. Vol. 55(1), pp. 5-14. doi: 10.1037/0003-066X.55.1.5

52. Shatté, A. J., Reivich, K., Seligman, M. E. P. (2000). Promoting Human Strengths and Corporate Competencies: A Cognitive Training Model // The Psychologist-Manager Journal. Vol. 4(2), pp. 183-196. doi: 10.1037/h0095891.

53. Snyder, C. R., Harris, C., Anderson, J. R., Holleran, S. A., Irving, L. M., Sigmon, S., Yoshinobu, L., Gibb, J., Langelle, C., Harney, P. (1991). The Will and the Ways: Development and Validation of an Individual-Differences Measure of Hope // Journal of Personality \& Social Psychology. Vol. 60(4), pp. 570-585. doi: 10.0.4.13/0022-3514.60.4.570

54. Stajkovic, A., Luthans, F. (1998). Self-efficacy and Work-related Performance: A Meta-analysis // Psychological Bulletin. Vol. 124, pp. 240-261. doi: 10.1037/0033-2909.124.2.240

55. Sweetman, D., Luthans, F., Avey, J. B., Luthans, B. C. (2011). Relationship between Positive Psychological Capital and Creative Performance // Canadian Journal of Administrative Sciences / Revue Canadienne Des Sciences de l'Administration. Vol. 28(1), pp. 4-13. doi: 10.1002/cjas.175 
56. Tang, J.-J. (2020a). Psychological Capital and Entrepreneurship Sustainability / In Frontiers in Psychology. Vol. 11, p. 866. doi: 10.3389/ fpsyg.2020.00866

57. Tang, J.-J. (2020b). Psychological Capital of Entrepreneur Teams and Human Resource Development / In Frontiers in Psychology. Vol. 11, p. 274. doi: 10.3389/fpsyg.2020.00274

58. Taştan, S. B. (2016). Psychological Capital: A Positive Psychological Resource and its Relationship with Creative Performance Behavior // Psikolojik Sermaye: Bir Pozitif Psikoloji Kaynağı ve Yaratıcı Performans Davranışı Ile İlişkisi. Vol. 16(1), pp. 101-118. doi: 10.18037/ausbd.389199

59. Tierney, P., Farmer, S. M. (2002). Creative Self-efficacy: Its Potential Antecedents and Relationship to Creative Performance // Academy of Management Journal. Vol. 45(6), pp. 1137-1148. doi: 10.5465/3069429
60. Tierney, P., Farmer, S. M. (2011). Creative Selfefficacy Development and Creative Performance over Time // Journal of Applied Psychology. Vol. 96(2), pp. 277-293. doi: 10.1037/a0020952

61. Wang, Y., Tsai, C.-H., Tsai, F.-S., Huang, W., Cruz, S. (2018). Antecedents and Consequences of Psychological Capital of Entrepreneurs // Sustainability. Vol. 10, p. 3717. doi: 10.3390/ su10103717

62. Youssef, C. M., Luthans, F. (2007). Positive Organizational Behavior in the Workplace: The Impact of Hope, Optimism, and Resilience // Journal of Management. Vol. 33(5), pp. 774800. doi: $10.1177 / 0149206307305562$

The paper submitted: August 5, 2020

Prepared for publication: December 10, 2020

\section{Evelina SAVICKAITĖ-KAZLAUSKE் \\ STUDENTỤ VERSLUMO PSICHOLOGINIO KAPITALO (PSYCAP) IŠTEKLIAI IR JỤ SANTYKIS SU KŪRYBINIU SAVIVEIKSMINGUMU}

\section{S a n t r a u k a}

Šiame darbe siekiama analizuoti studentų, dalyvaujančių Verslumo akademijos programoje, psichologinio kapitalo (PsyCap) bei kūrybinio saviveiksmingumo lygius bei panagrinèti tarpusavio sąsajas. Straipsnio teorineje dalyje pristatoma psichologinio kapitalo (PsyCap) raida bei svarba organizaciniame, ypač antreprenerystes, kontekste. Analizuojamos kūrybinio saviveiksmingumo sąsajos su PsyCap bei šios sąveikos reikšmé verslumo srityje. Aptariami naujausi tyrimai, paskatinę analizuoti PsyCap sąvokas, konstrukto sudedamąsias dalis (saviveiksmingumas, viltis, atsparumas bei optimizmas) ir jų sąsajas organizaciniu bei antreprenerystès edukacijos požiūriu. Empirinio kiekybinio tyrimo tikslas buvo pristatyti bei išanalizuoti verslumo programoje dalyvaujančių studentų psichologinio kapitalo (PsyCap) lygius ir palyginti su jaunų žmonių reprezentatyvios imties rezultatais. Kitas tyrimo tikslas buvo nustatyti kūrybinio savi-veiksmingumo išteklių lygị îvertinant sąsajas su psichologinio kapitalo bei atskirų jų skalių duomenimis (PsyCap). Kartu buvo siekiama paanalizuoti PsyCap bei jų skalių duomenų papildomus ryšius su antreprenerystès planais bei dabartine darbine padettimi.

Psichologinis kapitalas (PsyCap) (Luthans, 2002) per pastaruosius kelis dešimtmečius tyrinejjamas siekiant optimizuoti organizacijų žmogiškąsias sistemas. Dabartinis sudetingas ekonominis klimatas, kuriam daro itakos Covid-19 sukelta pandemija, kelia baimę ir neužtikrintumą dèl galimo ekonominio nuosmukio ir neaiškių perspektyvų (Nicola ir kt., 2020). Didesni psichologinio potencialo ištekliai gali turèti teigiamos ịtakos jaunųjų verslininkų bei antrepreneriu gebèjimui įveikti kliūtis ir spręsti problemas žengiant $\mathfrak{i}$ verslo pasaulị (Tang, 2020a). Kūrybinis saviveiksmingumas gali turèti svarbios ịtakos generuojant ir igyvendinant idejas (Tierney, Farmer, 2002; Chen, Zhang, 2019) bei kuriant naujas tvarias įmones nenumatomomis aplinkybemis. Literatūroje teigiama, kad PsyCap skatina kūrybiškumą (Tierney, Farmer, 2002), o konstruktų tarpusavio santykis gali daryti ịtakos tvariai verslumo sékmei (Tang, 2020a).

Tyrimo imtị sudare 43 Verslumo akademijos studentai (34,9 \% (15) vyrai, 65,1 \% (28) moterys). 
Duomenims rinkti buvo naudojami kiekybiniai metodai. Psichologinis kapitalas (PsyCap) buvo ivvertintas naudojant PCQ-24 testą (Luthans ir kt., 2007), o kūrybinis saviveiksmingumas matuotas pagal jo vertinimo skalę (Tierney \& Farmer, 2002). Rezultatai atskleidè, kaip ir tikètasi, kad Verslumo akademijos studentai turejjo statistiškai reikšmingai didesnius PsyCap ịverčius nei reprezentatyvi jaunų žmonių grupè, tačiau, priešingai nei buvo tikètasi, nebuvo atrasta reikšmingų ryšių tarp PsyCap ir kūrybinio saviveiksmingumo. Vienintelès iš keturių PsyCap saviveiksmingumo skalès ịverčiai atspindejo tam tikras teigiamas koreliacines tendencijas. Panagrinejus skirtingas PsyCap sub-skales galima pastebeti, kad dirbantys ir studijuojantys dalyviai yra aukštesnio vilties ir saviveiksmingumo lygio. Tie, kurie jau užsiima verslu, arba tie, kurie ketina siekti užsiimti verslumu ar net dar neapsisprendę, turi statistiškai reikšmingai didesnius PsyCap išteklius nei tie, kurie tokių ketinimų neturi. 